\section{リンゴコカクモンハマキの雄成虫を用いた薬剤 感受性簡易検定法の検討}

\author{
舟 山健 \\ 秋田県果樹試験場鹿角分場
}

Simple Bioassay for Monitoring Insecticide Resistance using Male Adults of Summer Fruit Tortrix, Adoxophyes orana fasciata WALSINGHAM (Lepidoptera: Tortricidae). Ken Funayama (Kazuno Branch, Akita Fruit-Tree Experiment Station, Hanawa, Kazuno, Akita 0i 8-52, Japan). Jpn. J. Appl. Entomol. Zool. 41 : 240-242 (1997)

Abstract: Comparative chlorpyrifos susceptibilities were examined in male adults and 5 th-instar larvae between resistant and susceptible populations of the Summer Fruit Tortrix, Adoxophyes orana fasciata. The susceptibilities were similar and parallel in both stages in each population. Monitoring of chlorpyrifos resistance is possible by treating male adults captured in sex-pheromone traps using a bodydipping method.

Key words: chlorpyrifos resistance, monitoring, male adult, Summer Fruit Tortrix

秋田県南部のリンゴ園ではリンゴコカクモンハマキ Adoxophyes orana fasciata WAISINGHAM の chlorpyrifos に対する抵抗吽発涬が哊 認されているが, 本種の chlorpyrifos 抵抗性の分布は本晾北部に は及んでいない(舟山・高橋, 1995)。薬剤抵抗性の発達を事前に 予測することは難しい(浜, 1992)が，的確な防除を行うために は個々の農家が本種の薬剂感受性の実態を把握しておくことが 重要である。数種の鱗翅目害虫では性フェロモントラップで捕 獲した雄成虫を用いた薬剂感受性のモニタリングが行われてい る (Suckling et al., 1985; Campaniola and Plapp, 1989 ; 広瀬· 浜, 1996)。

そこで, リンゴコカクモンハマキの楽剤感受性簡易検定法を 確立するための基礎資料を得る日的で, chlorpyrifos 抵抗性個体 群と感受性個体群を用い, 幼虫と成虫の薬剂感受性の比較と性 フェロモントラップで捕獲した雄成虫の chlorpyrifosに対する感 受性簡易検定の検討を行ったので報告する。

本文に入るに先立ち，本稿のご校閲をいただいた農林水産省 果樹試験場リンゴ支場虫害研究室坂神泰輔公辰ならびに秋田眎 果樹試験場高橋倠治場辰に厚く御礼申しトげる。また，有益な ご意見と文献をいただいた日本植物防疫協会研究所和同豊 氏， chlorpyrifos 抵抗性リンゴコカクモンハマキを提供していた だいた秋田県果樹試験場大隅専一氏ならびに試験にご協力いた だいた鹿角分場阿部基子氏に謝意を表する。

材料と方 法

\section{5 齢幼虫の薬剤感受性検定}

Chlorpyrifos 抵抗性個体群 (5 路令幼出の $\mathrm{LC}_{50}$ は $500<\mathrm{ppm}$ )
は 1994 年に秋田県平鹿町明沢のリンゴ園から, 感受性個体群 $\left(\mathrm{LC}_{50}=43.7 \mathrm{ppm}\right)$ は 1995 年に秋田県鹿角市寺坂のリンゴ園か ら, 越冬世代幼虫を採集して恒温室 $\left(24 \pm 1^{\circ} \mathrm{C}, 16 \mathrm{~L}-8 \mathrm{D}\right)$ で人工 飼料インセク夕 $\mathrm{LF}$ (日本農産工業(侏)を飭として飼育し, 1 世代 経過させた 5 齢幼虫を供試した。供試薬剂は Table 1 に示した 市販の殺虫剂 20 剂を常用濃度に, さらに chlorpyrifos $25 \%$ 水 和剂は抵抗性個体群には $63 \sim 1,000 \mathrm{ppm}$, 感受性個体群には 16〜250 ppm の 5 段階濃度に水 (展着剂アイヤー ${ }^{\circledR} を 10,000$ 倍 で加用)で希瀵し供試した。

薬剤感受性検定は葉片浸漬法により 1 区 10 頭 3 反復で行っ た。供試薬液にリンゴ葉 (品種: ‘ふじ’, 葉面積 $20 \sim 25 \mathrm{~cm}^{2}$ ) を 10 秒間浸漬した後に室内で風乾後, プラスチックカップ (径 8 $\times 4.5 \mathrm{~cm}$ ) に5〜7 葉入れて供試虫を放し, 上蓋 (無孔) を閉め て上記の恒温室内に置いた。調查は処理 48 時間後に生存虫, 死亡虫および苦閏虫を計数した。死虫率は共食いによる死亡虫 を除き苦悶虫を含めて算出し, 無処理区の死虫率で補正した。

\section{2. 成虫の薬剤感受性検定}

Chlorpyrifos 抵抗性個体群 (5 齢幼虫の $\mathrm{LC}_{50}$ は $500<\mathrm{ppm}$ ) は 1995 年に秋田県平鹿町醍醐の秋田県果樹試験場内國場から第 1 世代幼虫を, 感受性個体群 (5 齡幼虫の $\mathrm{LC}_{50}=43.7 \mathrm{ppm}$ ) は 1995 年に秋田県鹿角市寺坂のリンゴ園から越冬世代幼虫を採集し て, 前項と同じ条件で飼育し 3 世代経過させた日龃 1 日の成 虫を供試した。供試薬郕および chlorpyrifosに対する感受性検定 の希釈濃度は前項と同様である。

薬剂感受性検定は虫体浸漬法により1区 5１0 頭 3 反復で 行った。武田式粘着板 (武田薬品工業(侏) を $6 \times 15 \mathrm{~cm}$ に切断 し，供試虫を粘着面に背面を上に付着させ，供試薬液に成虫の 付着した粘着板を 10 秒間浸漬した後に室内で風乾後，前項の 恒温室内に置いた。調査は処理 24 時間後に生存虫，死亡虫お よび苦悶虫を計数し，死虫率は苦䦥虫を含めて算出した。な お，無処理区での死虫率はいずれも $0 \%$ であった。

3. 野外個体群の 5 龄幼虫と性フェロモントラップで捕獲し た雄成虫の chlorpyrifos に対する感受性検定

1996 年に秋田県鹿角市のリンゴ園 2 園地 (鹿角市関上, 鹿角 市寺坂) から越冬世代幼虫を採集して, 前項と同じ条件で飼育し 1 世代経過させた 5 齢幼虫と，1996 年 6 月 17 日に武田式粘着 トラップ (武田薬品工業(侏) を 1 園地に 6 枚置き翌朝 10〜11 時 に回収して，捕獲した越冬世代の雄成虫を１区トラップ। 枚 (78〜166 頭) ずつ供試した。供試薬剂は chlorpyrifos $25 \%$ 水和 剂を 16〜250 ppm の 5 段階濃度に水 (展着郕アイヤー ${ }^{\circledR} を$ 10,000 倍で加用) で希釈し供試した。

薬剂感受性検定および調查は，5齢幼虫は葉片浸清法で，性 フェロモントラップで捕獲した雄成虫はポリバケッ 径 $30 \times 30$ $\mathrm{cm})$ に供試薬液を入れ雄成虫の付着した粘着板を 10 秒間浸漬

日本応用動物昆虫学会誌 (応動昆) 第 41 巻 第 4 号：240 242 (1997)

1997 年 3 月 14 日受領 (Received 14 March 1997)

1997 年 7 月 1 日登載決定 (Accepted 1 July 1997) 
Table 1. Insecticide susceptibility of chlorpyrifos-resistant $(\mathbf{R})$ and -susceptible (S) populations of Summer Fruit Tortrix, Adoxophyes orana fasciata

\begin{tabular}{|c|c|c|c|c|c|c|c|}
\hline \multirow{3}{*}{$\begin{array}{c}\text { Insecticide } \\
(\text { formulation }, \%)\end{array}$} & \multirow{3}{*}{$\begin{array}{l}\text { Concentration } \\
\text { (dilution) }\end{array}$} & \multicolumn{6}{|c|}{$\%$ Mortality } \\
\hline & & \multicolumn{2}{|c|}{ 5th-instar larvae } & \multicolumn{4}{|c|}{ Adults } \\
\hline & & $\mathbf{R}^{\mathrm{b}, \mathbf{e}}$ & $\mathrm{S}^{\mathrm{c}, \mathrm{f}}$ & $\mathrm{R}$ 우 $\mathrm{c,g}$ & $\mathbf{R} \delta^{\lambda c, g}$ & $\mathrm{~S}$ 우 $\mathrm{c}, \mathrm{f}$ & $\mathrm{S} \delta \mathrm{c}, \mathrm{f}$ \\
\hline Chlorpyrifos (W, 25) & $\times 1000$ & 29.4 & 100 & 13.3 & 20.0 & 80 & 100 \\
\hline Thiodicarb $(\mathbf{W}, 75)$ & $\times 1000$ & 100 & 100 & 10 & 0 & 0 & 14.3 \\
\hline Prothiophos $(\mathbf{W}, 32)$ & $\times 800$ & 100 & 90 & 16.7 & 20 & -d) & 12.5 \\
\hline Fenpropathrin $(\mathrm{W}, 10)$ & $\times 1000$ & 95 & 100 & 80 & 90 & 83.3 & 100 \\
\hline Permethrin $(\mathbf{W}, 20)$ & $\times 2000$ & 94.7 & 90 & 20 & 43.3 & 0 & 42.9 \\
\hline Bifenthrin $(\mathbf{W}, 2)$ & $\times 1000$ & 89.5 & 80 & 50 & 70 & 14.3 & 85.7 \\
\hline Phenthoate (W, 40) & $\times 800$ & 85 & 73.3 & 66.7 & 100 & 60 & 100 \\
\hline Cypermethrin $(\mathbf{W}, 6)$ & $\times 1000$ & 75 & 80 & 10 & 40 & 14.3 & 14.3 \\
\hline Fenitrothion $(\mathrm{W}, 40)$ & $\times 800$ & 63.6 & 60.6 & 56.7 & 56.7 & - & 25 \\
\hline Salithion $(\mathbf{W}, 25)$ & $\times 1000$ & 60 & 100 & 60 & 100 & 85.7 & 71.4 \\
\hline Alanycarb $(\mathbf{W}, 40)$ & $\times 1000$ & 50 & 43.3 & 36.7 & 70 & 42.9 & 71.4 \\
\hline $\begin{array}{l}\text { Fenvalerate }(\mathbf{W}, 10) \\
\text { Fenitrothion }(\mathbf{W}, 30)\end{array}$ & $\times 1000$ & 50 & 44.8 & 40 & 60 & 16.7 & 42.9 \\
\hline Cyhalothrin $(\mathbf{W}, 5)$ & $\times 2000$ & 40 & 40 & 10 & 20 & 0 & 14.3 \\
\hline Diazinon $(\mathbf{W}, 34)$ & $\times 1000$ & 25 & 17.2 & 100 & 100 & 100 & 100 \\
\hline Carbaryl $(\mathbf{W}, 50)$ & $\times 800$ & 15.8 & 30 & 30 & 50 & 40 & 40 \\
\hline Fluvalinate $(\mathbf{W}, 20)$ & $\times 2000$ & 6.6 & 0 & 20 & 20 & 0 & 0 \\
\hline Dichlorvos $(E, 50)$ & $\times 1500$ & 5.6 & 0 & 86.7 & 90 & 100 & 100 \\
\hline Methidathion $(\mathbf{W}, 36)$ & $\times 1500$ & 5.3 & 6.6 & 10 & 30 & - & 37.5 \\
\hline Cyfluthrin (E, 5) & $\times 2000$ & 6.9 & 30 & 100 & 90 & - & 71.4 \\
\hline Tralomethrin $(F, 1.4)$ & $\times 2000$ & 0 & 10 & 23.3 & 70 & 50 & 71.4 \\
\hline
\end{tabular}

a W : Wettable powder; E : Emulsifiable concentrate; F : Flowable.

b 1994. c $1995 . \quad$ d Not examined.

e Resistant Akesawa population.

I Susceptible Terazaka population.

g Resistant Daigo population.

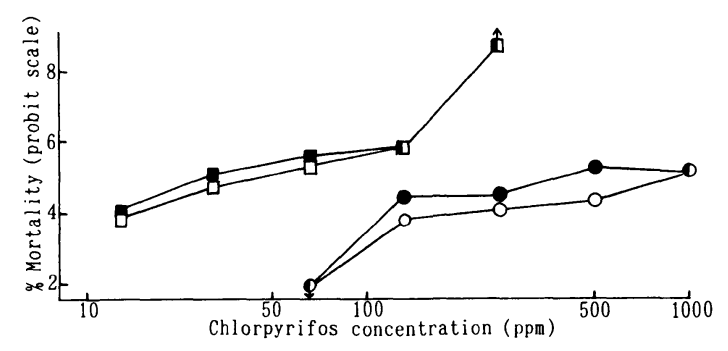

Fig. 1. Chlorpyrifos susceptibility of male adults and 5thinstar larvae of Summer Fruit Tortrix (Adoxophyes orana fasciata) in 1995. O: Male adults of resistant Daigo population, : 5th-instar larvae of resistant Akesawa population, $\square$ : Male adults of susceptible Terazaka population, - 5th-instar larvae of susceptible Terazaka population.

した後, 前項と同様に行った。なお, 無処理区の死虫率は関上 個体群が $8.8 \%$, 寺坂個体群が $6.0 \%$ であった。

\section{結果および考察}

リンココカクモンハマキの chlorpyrifos 抵抗性個体群と感受性 個体群の 5 齢幼虫と成虫の薬剂感受性検定結果を Table 1 に示 した。5 齢幼虫の抵抗性個体群と感受性個体群の薬剂感受性の

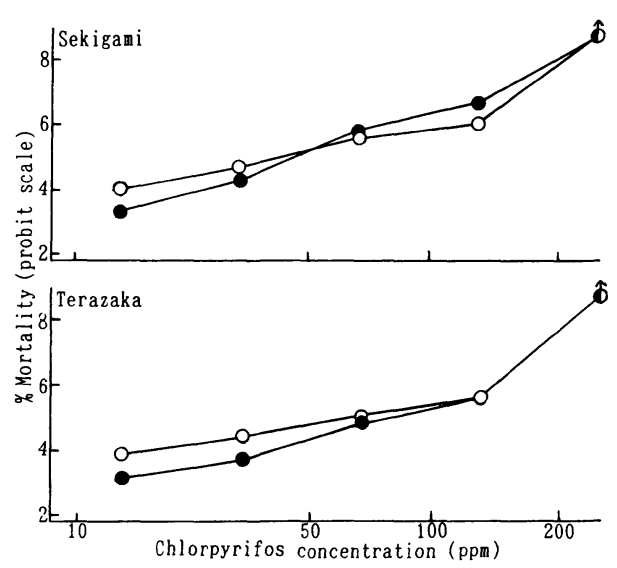

Fig. 2. Chlorpyrifos susceptibility in two field populations of male adults captured in sex-pheromone traps and 5thinstar larvae of Summer Fruit Tortrix (Adoxophyes orana fasciata) in 1996. $\bigcirc$ : Male adults captured in sex-pheromone traps, : 5th-instar larvae.

比較では，大部分の供試薬剤に対する死虫率はほほ同等であっ たが, chlorpyrifos 水和剂以外に salithion 水和剤に対する死虫率 は抵抗性個体群の方が感受性個体群より低かった。秋田県南部 
産の chlorpyrifos 抵抗性個体群は salithion に対しても感受性低 下が認められている (舟山, 1992) が, 抵抗性個体群と感受性個 体群の交雑個体群の感受性検定結果から, 本種の chlorpyrifos と salithion に対する交差抵抗性の可能性は低いと考えられている (舟山・高橋, 1995)。

Chlorpyrifos 抵抗性個体群と感受性個体群における成虫の薬剂 感受性の比較では, 大部分の供試薬剂に対する死虫率はほほ同 等であったが, chlorpyrifos 水和剂に対する死虫率は抵抗性個体 群の方が感受性個体群よりかなり低かった。また，雌成虫と雄 成虫の薬棛感受性の比較では, 全般に雌成虫の方が雄成虫より 死虫率がやや低かった。

鳞翅目害虫の薬剤感受性を幼虫と成虫で直接比軧した報告は 少ない。コナガの幼虫と成虫の各種有機リン剤に対する感受性 の比較では, 大部分の有機リン剂で抵抗性比がほほ同等であっ たが, cyanofenphos など 3 薬剤に対する抵抗性比は幼虫の方が 成虫より大きかった (浜, 1988)。また，ハスモンヨトウの薬郕感 受性系統と抵抗性系統の幼虫と雄成虫の methomyl に対する感 受性の比較では，雄成虫における抵抗性比は幼虫における抵抗 性比に比べかなり小ざかった(広瀬・浜, 1996)。

本種の幼虫の感受性を成虫の感受性から推定するための 5 齢 幼虫と成虫の薬剤感受性の比較では, 半数以上の供試薬郕に 対する死虫率はほほ同等であったが, thiodicarb 水和郕, prothiophos 水和剤, permethrin 水和剂および cypermethrin 水和剂 に対する死虫率は幼虫の方が成虫よりかなり高く，逆に diazinon 水和剤, dichlorvos 乳剤, cyfluthrin フロアブル剤, tralomethrin フロアブル剤に対する死虫率は成虫の方が幼虫より かなり高かった。今回の感受性検定は 5 齢幼虫は葉片浸漬法 で, 成虫は虫体浸漬法で行ったことから, 食毒性が高い thiodicarb での死虫率は, 成虫では低くとも幼虫では高い做が得 られたのは当然である。

リンゴコカクモンハマキの chlorpyrifos 水和剂に对する死虫率 は, 雄成虫と 5 齡幼虫はほほ同等で, chlorpyrifos 抵抗性個体群 と感受性個体群の雄成虫の死虫率は明らかに異なった。 Chlorpyrifos 抵抗性個体群と感受性個体群の雄成虫と 5 粉幼虫 の chlorpyrifos 水和郕に対する濃度一死虫率線を Fig. 1 に示し た。抵抗性個体群と感受性個体群の雄成虫の $\mathrm{LC}_{50}$ 値の比は 19.5 $\left(\mathrm{LC}_{50}\right.$ ：抵抗性個体群 $=860.0 \mathrm{ppm}(y=1.70 x+0.01, p=0.05$ で適
合していないが, 個体群間の感受性を比較するために使用した), 感受性個体群 $=44.0 \mathrm{ppm}(y=2.41 x+1.04, p=0.05$ で適合)), 抵 抗性個体群と感受性個体群の 5齢幼虫の $\mathrm{LC}_{50}$ 值の比は 17.9 $\left(\mathrm{LC}_{50}\right.$ : 抵抗性個体群 $=584.8 \mathrm{ppm}(y=1.33 x+1.32, p=0.05$ で適 合していないが, 個体群間の感受性を比較するために使用し た), 感受性個体群 $=32.7 \mathrm{ppm}(y=2.2 x+1.67, p=0.05$ で適合)) で, 雄成虫と 5 齢幼虫の chlorpyrifos 感受性に大きな差は認め られなかった。野外 2 個体群の性フェロモントラップで捕獲し た雄成虫と 5 齢幼虫の chlorpyrifos 水和剤に対する濃度一死虫率 線を Fig. 2 に示した。両個体群の雄成虫の LC $_{50}$ 値の比は 0.75 ( $\mathrm{LC}_{50}$ : 関上個体群 $=40.0 \mathrm{ppm}(y=2.58 x+0.87, p=0.05$ で適合), 寺坂個体群 $=53.2 \mathrm{ppm}(y=2.34 x+0.96, p=0.05$ で適合)), 両個 体群の 5 齢幼虫の $\mathrm{LC}_{50}$ 值の比は $0.60\left(\mathrm{LC}_{50}\right.$ : 関上個体群 $=41.9$ ppm ( $y=4.03 x-1.54, p=0.05$ で適合), 寺坂個体群 $=69.5 \mathrm{ppm}$ $(y=3.3 x-1.08, p=0.05$ で適合))で, 性フェロモントラップで捕 獲した雄成虫と 5 齡幼虫の chlorpyrifos 感受性に大きな差は認 められなかった。

以上の結果から, リンゴコカクモンハマキの chlorpyrifos 感受 性は, 性フェロモントラップで捕獲した雄成虫を用いてもモニ タリングが可能と考えられる。しかし，性フェロモントラップ で捕獲したハスモンョトウ雄成虫では, 薬剤処理方法によって は, 日齢や採取時期で薬剤感受性が異なる (広瀬・浜, 1996)こ とから, 本種でもさらに詳しい調查を行い, 再検討する必要が ある。

\section{引用 文 献}

Campanhola, C. and F.W. Plapp, Jr. (1989) J. Econ. Entomol. 82 : 22-28.

舟山 健 (1992) 今月の農業 36 (1 1) : 36-40.

舟山健·高橋佑治 (1995) 応動昆 39: 81-83.

浜 弘司 (1988) 応動昆中国支会報 $30: 51-55$.

浜 弘司 (1992) 害虫はなぜ農薬に強くなるのか. 東京: 農山 漁村文化協会, pp. 148-149.

公瀨拓也 ·浜 弘司 (1996) 応動昆 40: 61-69.

Suckling, D.M., D.R. Penman, R.B. Chapman and C.H. Wearing (1985) J. Econ. Entomol. 78 : 204-207. 